\title{
Role of Complements and Immunoglobulins in Alzheimer's Disease
}

\author{
Sanjeev Kumar1 ${ }^{*}$, Reena Mittal ${ }^{2}$, Shweta Chaudhary', Depp Chand Jain ${ }^{3}$ \\ ${ }^{1}$ Department of Physics, Central Medical Physics Research Laboratory, D.A.V. (P.G.) College, \\ Muzaffarnagar, India \\ ${ }^{2}$ Department of Mathematics, Shri.K.K.JAIN. College, Muzaffarnagar, India \\ ${ }^{3}$ Department of Neurology, Safdarganj Hospital, New Delhi, India

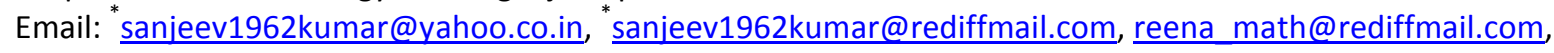 \\ drdcjain@gmail.com
}

Received 20 March 2014; revised 23 April 2014; accepted 30 April 2014

Copyright (C) 2014 by authors and Scientific Research Publishing Inc.

This work is licensed under the Creative Commons Attribution International License (CC BY). http://creativecommons.org/licenses/by/4.0/

(c) (i) Open Access

\section{Abstract}

Our findings show that the value of IgG in serum of Alzheimer's Disease patients is (17.2059 \pm 2.6317) $\mathrm{g} / \mathrm{l}$ and in controls i.e. $(17.6720 \pm 3.1457) \mathrm{g} / \mathrm{l}$. Values of IgM in AD patients go down up to $62.5 \%$ in comparison to healthy subjects. A sudden change was observed in the levels of IgA of AD patients. It has been put on the value $137.9 \%$ high in comparison to healthy subjects. The levels of complement $C_{3}$ have also value of lower side and go down up to $52.66 \%$ in $A D$ patients. The value of levels of complement $\mathrm{C}_{4}$ shows no deflection from the control values. On the basis of regression and multiple correlation analysis, we found that the partial correlation coefficients $\mathbf{r}_{G A . M}$, which has value 0.44815 in AD patients and 0.45555 in controls, do not show any resemblance. The multiple partial correlation $r_{A M . G}$ has value 0.3082 in $A D$ patients and 0.3912 in controls slightly better correlated in comparison to healthy controls. Multiple $\mathbf{R}_{\text {A.MG }}$ has strongly correlation in comparison to controls. $\mathbf{R}_{\mathrm{M} . \mathrm{AG}}$ is also strongly correlated. Regression coefficients and regression equations are basic foundations of correlation measurements and show a specific character of variation. $A$ relation between all the three multiple correlations has been established in the present work and it is given by the following relation $R_{A . M G}>R_{M . A G}>R_{G . A M}$.

\section{Keywords}

Complements, Immunoglobulins, Alzheimer's Disease, Regression Coefficients, Multiple Correlation Coefficients

\footnotetext{
${ }^{*}$ Corresponding author.
} 


\section{Introduction}

Dr. Alois Alzheimer, a German physician, presented a case of 55-year-old woman in 1906 who was a patient of progressive dementia. A history of Alzheimer's disease has started with this case. Dementia has been recognized since early antiquity. It has been associated with old age [1]. Progressive mental deterioration in old age has been recognized and described nicely in the literature. Dr. Alzheimer specifically identified a collection of brain cell abnormalities as a disease. A patient of Dr. Alzheimer died after years of severe memory problems, confusion and difficulty in understanding the daily use of general questions. A brain autopsy of the dead body has been done and doctors noticed that dense deposits are surrounding the nerve cells (neuritic plaques). He observed twisted bands of fibres (neurofibillary tangles) in the nerve cells. Now adays, this degenerative brain disorder bears Dr. Alzheimer name. These plaques and tangles mean a definite diagnosis of Alzheimer's disease (AD). Many scientists discovered a link between cognitive decline and the number of plaques and tangles in the brain. The medical community then formally recognized Alzheimer's disease as a disease. It was not a part of aging. Reger, B. [2] has given new aspects regarding this disease. People are understanding that a grandparent, parent, elderly relatives, friends can no longer remember names or faces, recognize common objects or talk in coherent sentences of daily use. These persons may be suffering from Alzheimer's disease. This disease is a growing medical and social concern. A degenerative disorder attacks brain and leads to dementia. The brains cognitive centres are very much affected. A memory loss, inability to understand situations or even question or statements are the features caused by this disorder. Due to the progression of this disease, social interactions diminish and the person loses the ability to care for him or herself. It has been noticed that before the discovery of Alzheimer's disease, scientist and non-science community have given their views on dementia. A dementia is a natural progression of age and senility was accepted as a part of aging [3]. Ronald, C. H. et al. [4] have reported in literature that Ronald Reagen had Alzheimer's disease galvanized the American public into recognizing their own vulnerability in a way no other public figure has done. Norman Reckwell and Rita Hayworth were both victims of this disease. They were beloved and admired. Ronald Reagen challenged politicians and law makers to properly fund research into the complete exercise of cause and treatment of the disease. Cohen, G. D. [5] had put forward historical views and evolution concept related to Alzheimer's disease. Concepts of senile dementia in general have evolved for more than 2.5 thousand years. Alzheimer's disease had traced in the start of $20^{\text {th }}$ century. A relationship between Alzheimer's disease and senile dementia is not clear. A confusion has accompanied gamut of considerations about both these disorders. A focus has been nomenclature, epidemiology, etiology, diagnosis, clinical course, treatment, prognosis or prevention. This confusion has historically affected clinical practice, research and social response to both disorders. Memory is generally coming into playing an important role in the senility and senile dementia explanation. The memory in decline direction at old age has been observed. Neurofibriallary tangles and granulo vascular degeneration are described by Alzheimer and Simchowicz in 1906 and 1910 respectively. These were the major morphological additions. Rebecca, C. et al. [6] have projected an overview of environmental risk factors in neurodegenerative disease.

Alzheimer's disease is the prototypical degenerative disease affecting the central nervous system (CNS). This disease is a chronic progressive disease characterized by memory loss and deficits in one or more of cognitive domains. These are aphasia known as language disturbance, agnosia, apraxia, or executive function. Such types of deficits must be severe enough to interface with daily work of life. Alzheimer's disease is a form of brain disease, and can lead to confusion, memory loss, restlessness, problems with perception, speech trouble moving and fearing things, which were absent at that time. The patient may become too excited, refuse food and lose bowl or bladder control. This neurological perturbation generally starts in late middle life with slight deficits in memory and behavior. This disease occurs in both the sexes. The exact causative mechanism of the disease is unknown. It has been seen that there is a break-down of cells in the brain. There is no treatment of the disease available and a good neutrition may slow down the progress of Alzheimer's disease. This disease is no longer regarded as a natural consequence of aging. It affects a substantial proportion of the aged. Although the exact number of people affected is not exactly known because of the difficulties involved in accurate diagnosis, it is estimated and speculated that more than four million Americans people have this disease in its various stages. Ronald, C.H. et al. [7] have decided some factors that aggravate the symptoms in Alzheimer's disease. A generalized deterioration in functional activities of daily living is expected in patients with Alzheimer's disease. Progressive decline and gradual loss of higher cortical cognitive functions commonly spear head the deterioration. It has been seen that in some patients the rate of declining function and disability may accelerate. The reversible causes must be sought out at the time of acceleration of the disease. These causes must be treated actively. The 
underlying Alzheimer's disease process is not the cause of this sudden physical or mental deterioration. A person's mental functions are controlled by the brain, which is made up of $10^{10}$ nerve cells called neurons. Brain functioning depends on the number of brain cells, their integrity, and the efficiency of the blood circulation. Neurons have no neutrition stores. They depend entirely on the circulation to provide them with required and adequate quantities of glucose, oxygen and different types of other nutrients. An efficient circulation removes from the brain any waste or toxic elements that have been formed by the brain cells through their metablic activity. If the blood flow is ineffective, not only will the nerve cells be deprived but also different waste or toxic elements will accumulate in or around neurons. The nerve cells cannot function properly under these conditions. Greitz, N.H. [8] studied various inflammatory processes and suggested that cytokins may also have a role in the pathology of Alzheimer's disease. Inflammation is a general marker of the tissue damage in any disease. It may be either secondary to tissue damage in Alzheimer's disease or a marker of immunological response. Patterson, C., et al. [9] and Rosendorff, C., et al. [10] have studied and found that cardiovascular risk factor such as hypocholestrolaemia, hypertension, diabetes and smoking are associated with a high risk of onset and course of Alzheimer's disease. Soffrizzi, V., et al. [11] studied and found that the component of a mediteranean diet, which include fruit and vegetables, bread wheat and other cereals, olive oil, fish and red wine may reduce the risk factor of Alzheimer's disease. Master, C.L., et al. [12] and Glenner, G.G., et al. [13] have given informations regarding the pathology of Alzheimer's disease, which is very complex. There are extra cellular neuritic plaques, largely consisting of deposit of a peptide $\beta$-amyloid.

Panza, F., et al. [14] have studied the effect of light to moderate use of alcohol, particularly red wine associated with lower risk of Alzheimer's Disease. Stern, Y. [15] has studied cognitive reserve in Alzheimer's disease. He found that those people were engaged intellectual activities, such as reading playing board games, completing cross word puzzles, playing musical instruments or regular social interactions show a reduced risk of Alzheimer's disease. This is compatible with the cognitive reserve theory. This theory states that some life experiences result in more efficient neural functioning providing the individual a cognitive reserve that delays the onset of dementia manifestations. Some research [14] [15] have shown an increased risk of developing Alzheimer's disease with environmental factors such as intake of metals particularly aluminum. It has been reported in the literature that using Vitamin E by the Alzheimer's diseased person a significant improvement in the function of human system was also seen. A range of antioxidants is also applying to the Alzheimers to see the effect of the antioxidants to the patients. Interactions of metals like copper, zinc, iron and other metals are also studying these days to prevent the onset of this disease. The trace elements are needed for the normal brain function. A beta amyloid may be toxic due to the change in the trace elements. High blood cholestrol and blood pressure may also accelerate the onset of the disease. A high level of amino acid hemocysteine is associated with an increased risk of developing Alzheimer's. High blood pressure can damage blood vessels in the brain and reduce the brains oxygen supply. The resulting oxidative stress may accelerate the build-up of $\beta$-amyloid protein. Alzheimer's disease afflicts older people. It is increasing in incident with age significantly. Some of the researchers [16]-[18] have given their views as aging is associated with marked deterioration of the immune system. They have found a significant increase in the incident of autoimmune diseases. Kay, M.M.B., et al. [19] and Wechsler, M.E., et al. [20] have given information as the age-related decline in immune functions in partly the result of deterioration of thymus derived (T cell) functions. It may be related to the involution of the thymus. It has been reported that thymectomy accelerates the age related less of IgG and high affinity antibody response. Weksler, M.E. [21] has studied and reported that spleen cells from old animals were exposed to a young thymus gland or exogenous thymoprotein, the high affinity antibody response was completely restored. The neuropathological changes in Alzheimer's disease brain include neuronal loss, loss of dendritic spines and formation of neuritic (senile) plaques and neurofibrillary tangles. Wisniewski, H.G., et al. [22] have reported that underlying pathogenesis of plaques and neurofibrillary tangles is not clearly understood till now.

We wish to give a brief idea regarding various immunological factors which may play a significant role in the neuropathology of aging and Alzheimer's disease.

Many scientists [23]-[29] have provided some useful information regarding antibodies against neuronal structures in various neurological diseases such as multiple sclerosis, cerebrovascular accidents, schizophrenia, Hangtington's chorea and systemic lupus erythematosus. Ingram, C.R., et al. [30] have found the increased age related concentration of the $\gamma$-globulin fraction of human serum binds specifically with neurons in sections of human brain.

The CNS was believed to be immuneglocically privileged. Some of the researchers [31]-[41] have shown that 
it is not definitely true for Alzheimer's disease. It has been reported that the immune response and inflammation might began with scavenger cells, which phagocytes infected or damaged cells and the detritus of inflammatory response. If the scavenger cells bear major histocompatibility complex type II antigens on their surface, they can show processed fragments of their phagocytic activity, antigens, to T-and B-lymphocytes. T-helper lymphocytes are activated by such presentation and express cytokines, which activate other immune cells, specially B-cells that have also been presented with antigen. The B-cells proliferate and produce antibodies specially directed against the original antigenic stimulus. Antibodies binds to antigens in the tissue. Scavenger cells are redirected to sites of antibodies binding by means of receptors to an epitope on the $\mathrm{E}$ region of antibodies.

Classical pathway complement proteins also begin to attach to the antigen-antibody complex, beginning with $\mathrm{C}_{\mathrm{lq}}$ at on E site on antibody. The other complement proteins follow, culminating with the membrane attack complex such as $\mathrm{C}_{5}-\mathrm{C}_{9}$, which inserts pores in the cell wall. Some of the researchers [42] [43] have shown that cell lysis and phagocytic activity follow, with additional attraction of scavenger cells by means of binding sites on $\mathrm{C}_{3}$ and $\mathrm{C}_{5}$. It has been reported that detecting brain reactive antibodies in serum samples of Alzheimer's disease, as well as antibodies, presumably from the patient and bound before the patient's death co localized with Alzheimer's disease pathology [44] [45].

We may say that one possible source of difficulty in detecting Alzheimer's disease specific antibodies is complement. $\mathrm{C}_{\mathrm{lq}}$ binds to the $\mathrm{F}_{\mathrm{c}}$ region of immunoglobulins in the antibody-antigen complex. The remaining complement proteins then bind sequentially and may render critical epitopes on the immunoglobulin molecule inaccessible to anti-immunoglobulin antibodies. Moreover, binding affinities within the antigen-antibody- $\mathrm{C}_{1}$ complex are relatively weak. Specific immunoglobulin binding might not survive the rigors of autolysis and tissue preparation. During autolysis serum may leak from capillaries especially in the aged brain. It is difficult to detect antibodies in brain of Alzheimer's disease.

Gaskin, F., et al. [45] have reported that studies based on antibodies from B-lymphocytes cloned from Alzheimer's disease and non-Alzheimer's disease patients may provide some resolution to the problem of immunoglobulin antibodies detection.

When antibodies to complement protein including $\mathrm{C}_{1 \mathrm{q}}, \mathrm{C}_{4 \mathrm{~d}}, \mathrm{C}_{3 \mathrm{~d}}$ and $\mathrm{C}_{5 \mathrm{~b}-9}$ are applied to non demented elderly brain tissue, the sections were found to be as blank. If these are applied to Alzheimer's disease samples, intense immuno reactivity was observed in senile plaques, neurofibrillary tangles, and some neurons or dystrophic neurities. Presence of the membrane attack complex $\mathrm{C}_{5}-\mathrm{C}_{9}$ indicates that the target has been to be lysed. Some of the authors [46] [47] have shown that the data suggest that the loss of neurons and the appearance of plaques and tangles in Alzheimer's disease may in part be mediated by immune mechanisms.

Rogers, J., et al. [48] has reported that the immune response and inflammation are vital mechanisms in the body's defense schemes. They protect us from infectious agents and help cleanse regions of tissue damage. The CNS may be a singularly unreceptive organ for such types of benefits, whereas the removal of infected or weakened cells within and around a skin laceration may be a most helpful product of inflammatory mechanisms, it might not be in brain. New skin cells are always available to replace those last in the inflammatory attack. Neurons are post mitotic. It has been reported that chronic anti-inflammatory therapy in patients over 65 years of age may lesson or postpone the expression of Alzheimer's disease symptomatology.

Gottfries, C.G. [49] has studied biochemical changes in blood and CSF in Alzheimer's disease patients and reported that in living patient the investigation of CSF can give valid information about the metabolism in brain tissue.

It is possible that Alzheimer's disease is not entirely localised in the CNS. Some of the findings indicate that other parts of body are also involved in demanting disorder.

It may therefore also be of value to study changes in the blood. Findings in the blood may also reflect the metabolism of the brain to some extent.

Cohen, D., et al. [50] have given a thought for interrelationship between the CNS and immune functions. A correlation between serum levels of IgG and IgM found in Alzheimer's disease to be positive. The autiology of Alzheimer's disease may involve an infectious agent, such as a virus, the $\gamma$-globulin bonding in CSF from patients with presenile dementia has been studied.

William, A., et al. [51] have studied serum and CSF in presenile onset dementia. The electrophoretic pattern demonstrated three homogenous bands in the gamma globolin region in five of eight patients of Alzheimer's disease. The bands were not present in serum. It has been safely said that the bands found in the CSF of Alzheimer's disease patients supported the hypothesis that an infectious agent or abnormal regulation of the immune 
system is significant in the disease aetiology.

Rozemuller, J.M., et al. [52] and Eikelenboom, P., et al. [53] showed that amorphous and classical plaques contain the complement protein $\mathrm{C}_{1 q}, \mathrm{C}_{4}$ and $\mathrm{C}_{3}$. Some of the researchers [54] [55] have carried out the work on immuno-histochemical point of view and revealed the presence of the membrane attack complex in the corona of classical plaques. These findings indicate that in classical plaques an activation of the complement cascade had played an important role. The presence of $\mathrm{C}_{1 q}$ and the absence of properdin indicate that the classical and not the alternative, pathway is being activated. Complement activation can occur by mechanisms other than binding to immunoglobulins.

Rogers, J., et al. [55] have shown that $\beta / \mathrm{A}_{4}$ protein directly binds $\mathrm{C}_{1 q}$ without immunoglobulin mediation. The binding leads to functional activation classical pathway. These fabulous findings could explain the presence of activated complement proteins from an early stage in plaque development. Mc Geer, P.L., et al. [56] have used molecular biological techniques to study the complement levels such as $C_{1}, C_{3}$ and $C_{4}$ and found that these levels were lower in normal brains and are elevated several fold in Alzheimer's disease brains. Inhibitors of complement can resist complement lysis after the formation of the membrane attack complex at the cell surface.

The findings regarding the complement proteins in Alzheimer's diseased brains suggest that the system of complement is also entangled in the generation of the pathological hall marks in Alzheimer's disease.

Eikelenboom, P., et al. [57] have given a thought of amyloidal plaque formation and they found that this formation is closely associated with a local, induced inflammatory response. There is a weak but identifiable immune response in Alzheimer's disease. The immune response may contribute to the pathogenesis of Alzheimer's disease. It has already been established that there are autoantibodies against neural elements in Alzheimer's disease patients and that the specific anti-Alzheimer's disease brain antibodies were also present.

Fillit, H.M., et al. [58] showed that more intense staining of specific areas of normal rat and human brain with Alzheimer's disease sera. They have found some reactivity with a subpopulation of Alzheimer's disease sera. Inhibition studies eliminated this antibody reaction. They also found many other types of antibody reaction. Fillits, H.M., et al. [59] have demonstrated that the presence of antibodies against CNS vascular membrane in Alzheimer's disease sera. This reactivity was shown to be very specific for heaparan surface proteoglycan.

Singh, V.K., et al. [60] have studied adsorption aspects of Alzheimer's disease and control sera with pellets from various tissue homogenates. Sugiura, M., et al. [61] have reported a subpopulation of Alzheimer's disease sera to be positive for rabbit cerebellum neurons after absorption with liver acetone powder.

Cohen, D., et al. [62] have studied serum immunoglobulins and cognitive status in the elderly with reference to population. They have reported that IgG and IgA levels were elevated. The levels of IgM were not raised. Eisodorfer, C., et al. [63] have studied serum immunoglobulins and cognitive status in the elderly with reference to immunological behavioral relationship. They have found that serum IgG emerged as the single best predictor of behavioral status.

Koutsocraki, E. [64] studied immunological features in Alzheimer's disease and applied immunotherapy in this disorder and concluded that antibody immunization results in allevation of memory in transgenic mice. In human beings, active vaccination may result in a trend toward cognitive benefit in antibody responders. Responders show an increased rate of hippocampal atrophy by magnetic resonance imaging (MRI). Many autopsies showed plaque clearance.

Morgan, B.P., et al. [65] have studied the role of complement in disorders of the nervous system. The complement system plays important roles in host defense but activation at inappropriate sites or to on excessive degree can cause host tissue damage. Complement has been implicated as a factor in the causation or propagation of tissue injury in various brain disorders. The brain is an immunologically isolated site, sheltered from circulating cells and proteins of the immune systems. There is a growing body of evidence implicating complement in different brain diseases. Bonifati, D.M., et al. [66] have studied the role of complement in neurodegeneration and neuroinflammation. Complement system provides an innate mechanism against pathogenic microorganisms. CNS contains many components of the immune system, including components of the complement system, which are synthesized by astrocytes, microglia and neurons. A wide range of inflammatory markers, typically not present in the normal elderly persons and present in Alzheimer's disease patients. It has become an evidence of sustaining brain inflammation could be an essential cofactor in this disease and other neurological disorders such as Parkinson disease, dementia with Lewy bodies, Huntington's and prior diseases. The complement system may be useful in eliminating aggregated and toxic proteins associated with these neurological disorders and 
have a protective effect. However, an exaggerated or insufficient activation of the complement system can have deleterious effects through the activation of oxidative products.

Eikelenboom, P., et al. [67] have studied the role of complement and activated microglia in the pathogenesis of Alzheimer's disease. They have reported a variety of inflammatory mediators including complement activation products, protease inhibitors, and cytokines are co localized with $\beta$-amyloid deposits in the brain of Alzheimer's, activation products of the early component components $C_{1}, C_{3}$ and $C_{4}$ are found in neuritic plaques and to a lesser extent in varying number of diffuse plaques. No immuno histochemical evidence have been reported for the presence of late complement components $\mathrm{C}_{7}$ and $\mathrm{C}_{9}$ and the complement membrane attack complex in the neuropathological lesions in the brains of Alzheimer's. The late complement components $\mathrm{C}_{7}$ and $\mathrm{C}_{9}$ are not detectable. Authors have reported that the complement system does not act as inflammatory mediator through membrane attack complex formation. The complement system acts as an inflammatory through the actions of the $\mathrm{C}_{1}, \mathrm{C}_{3}$ and $\mathrm{C}_{4}$ complements only.

Watts, H., et al. [68] have studied the significance of antineuronal antibodies in Alzheimer's disease. They have used indirect immunofluorescence and cell type-specific markers to determine whether antibodies directed against specific neural cell type were present in patients with Alzheimer's disease. Other neurological disease and normal controls-sera and CSF were also tested. It has been established that all the samples were indistinguishable in their pattern of immunoglobulin staining. Staining of neurones on frozen sections was nuclear. Surface staining of neurones were seen in CSF and sera also.

Jean, M.B., et al. [69] have studied immunohistochemical characteristics of human choroid plexus in vascular and Alzheimer's dementia. They have also reported that the autoimmune alterations are indirectly supported in Alzheimer's disease by the demonstration of circulating antibodies directed to the epithelial basement membrane of the choroid plexus. Specific alterations were found in Alzheimer's disease patients only. These were comprised of pseudo linear deposits of immunoglobulin $G$ and Coarse deposits of $C_{1 q}$ along the thickened and segmented epithelial basement membrane. These were associated with IgM also. The findings suggest that immune alterations of autoimmune may be involved in Alzheimer's disease and leading to serve lesions of the choroid plexus. Such type's anomalies could be responsible for some of the alterations of cerebra-spinal fluid production or composition noted in the disease.

Elouaara, I., et al. [70] have studied CSF in Alzheimer's disease related to BDB function and intraethecal protein synthesis. They have found that the levels of IgG, IgA, transferring and albumin were elevated and very higher compared to the controls. CSF heptaglobin levels were also elevated. The increased CSF/serum ratio for IgG and CSF/albumin ratio suggest that there is an increased BBB permeability in this disorder.

Nerenberg, S.T., et al. [71] have studied cerebrospinal fluid IgG, IgA, IgM, IgD and IgE levels in CNS disorders and found that abnormal immunoglobulin levels occurred in all conditions such as multiple sclerosis, viral meningitis and tumors. The levels of IgA, IgM and IgE were higher in benign and malignant tumors of CNS. The ratio of immunoglobulin to protein in aspectic meningitis and multiple sclerosis was significant as compared to normals.

Selkoe, D.J. [72] studied biochemistry of altered brain proteins in Alzheimer's disease. The author suggested that the progressive dysfunction of limbic and association cortices in patients is accompanied by the formation of unusual intra-neuronal and extracellular proteinaceous filaments. These striking structural changes of neurons, their processes and adjacent cerebral microvessels provide a cytopathological signature of the disease. This is a feature often lacking in other neurological disorders.

Hampel, H., et al. [73] have studied serum and cerebrospinal fluid in Alzheimer's, major depresent and vascular demented patients. Their data related to CSF, CSF/Serum ratio albumin/IgG for Alzheimer's disease, vascular dementia and major depression cases support the hypothesis of a blood CSF barrier leakage in a subgroup of all patients. The levels of IgG were also elevated. The authors have quoted that elevated CSF immunoglobulins combined with the blood CSF barrier impairment might be associated or caused by a general immune activation. Their data show that blood CSF barrier impairment and elevation of IgG immunoglobulin level were unspecific either for Alzheimer's disease, vascular dementia and major depression.

Constantin, B., et al. [74] have studied humoral immunity in aging brain and Alzheimer's disease. They suggested that human immunoglobulins can interact with tau protein and alter both the dynamics and structural organization of microtubules.

Veerhuis, R., et al. [75] have studied complement activation in amyloid plaques in Alzheimer's disease brains. Authors have suggested that in Alzheimer's disease high levels of the early components $C_{1}, C_{4}$ and $C_{3}$ were very 
much present to allow the complement pathway to proceed until $\mathrm{C}_{3}, \mathrm{C}_{1}$ through $\mathrm{C}_{3}$ can be associated with $\beta / \mathrm{A}_{4}$ deposits in Alzheimer's and controls, irrespective of the presence or absence of tau pathology or activated glial cells.

Kalaria, R.M., et al. [76] have studied serum proteins and the BBB in the pathogenesis of Alzheimer's disease. It has been seen that a variety of classical serum proteins including protease inhibitors involved in the coagulation. Cascade is intimately associated with the pathological lesions of Alzheimer's disease. There is no way to have a clear cut association of these molecules which may play a significant role in the pathogenesis of the disease. Authors have embarked on studies to examine the localization and origin of these amyloid associated factors in Alzheimer's disease. Authors have demonstrated that serum amyloid component and the three homologous serpins, $\alpha$-antichymotrypsin, antitrysin and antithrombin II, are all localized in amyloid deposits. It has been conventionally considered that the localization of plasma proteins in parenchymal amyloid deposits are to be evidences for breach of the BBB in Alzheimer's disease. Authors have enlighted that the brain has the remarkable capacity to express classical serum proteins during degenerative processes similar to chronic inflammatory response in the periphery.

Kayeed, R., et al. [77] have studied and reviewed in Alzheimer's disease emerging role of treatment for intravenous immunoglobulins. They reported that intravenously immunoglobulins preparations may be effective because they contain both anti-tau and anti- $\mathrm{A} \beta$ natural antibodies. Apart from the presence of these antibodies, intravenously immunoglobulin may be useful for Alzheimer's disease treatment due to anti-inflammatory effects at high doses mediated in part via Fc receptor uptake of IgG by inflammatory cells.

Kumar, S., et al. [78] have used the method of Mancini, G., et al. [79] in epileptic children and found that the value of IgG was higher in comparison to helathy children and other immunological parameters such as IgA, IgM, $\mathrm{C}_{3}$ and $\mathrm{C}_{4}$ were lower than controls.

\section{Materials and Method}

\subsection{Selection and Exclusion of Patients}

We have selected Alzheimer's diseased patients and normal healthy controls whose aged group has a range of 50 to 69 years. The patients were on standard medicines. We did not select above this age group. Blood samples of these patients were collected from the Department of Neurology, Safdarjang Hospital, New Delhi 110016 after the approval of ethical committee of the hospital. 10 milliliters freshly drawn blood from each patient was collected in clean and dry test tube without any anti-coagulant. The test tube was kept for 45 minutes at room temperature $\left(22^{\circ} \mathrm{C} \pm 2^{\circ} \mathrm{C}\right)$ for the formation of clot. Sera of different patients and normal healthy controls were separated by centrifugation at 1500 r.p.m. up to 15 minutes and were collected in screw capped test tubes.

The immunological parameters (IgA, IgG, IgM, $\mathrm{C}_{3} \& \mathrm{C}_{4}$ ) were quantitied by using singles radial immunodiffusion method of Mancini et al. [79] using commercially available antibody-agar plates. The plates were standardized with purified immunoglobulins. The purpose is to quantitate serum levels of immunoglobulins (IgG, IgA, IgM) and complements $\left(\mathrm{C}_{3}\right.$ and $\left.\mathrm{C}_{4}\right)$. These measurements aid in the clinical diagnosis, assessment of disease activity, response to treatment, and follow-up in patients with various clinical conditions. Measurements of immunoglobulin A (IgA) and immunoglobulin M (IgM) aids in the diagnosis of abnormal protein metabolism and the body's lack of ability to resist infectious agents.

Measurements of IgG aids in the diagnosis of autoimmune diseases, sarcoidosis, chronic liver disease, chronic and recurrent infections, lymphoid malignancies, multiple myeloma and severe and variable immunodeficiency. The complements system is the main mediator mechanism of humoral immunity. To study the levels of complements $\mathrm{C}_{3}$ and $\mathrm{C}_{4}$ is also our object regarding the complete knowledge of immune system in Alzheimer's disease.

\subsection{Results}

Experimental findings are given in Table 1.

We have applied statistical analysis such as regression and correlation with Student "t"-test to analyze the data for a concrete foundation of authenticity. The regression and correlation coefficients are given in Table 2. Student " $\mathrm{t}$ "-test was applied and given in Table 3. 
Table 1. Experimental findings in epilepsy and Alzheimer’s disease neurological disorders.

\begin{tabular}{|c|c|c|c|c|c|}
\hline 1 & IgG & Serum & $(18.18 \pm 4.71) \mathrm{g} / \mathrm{l}$ & $\mathrm{E}$ & Kumar, S., et al. [78] \\
\hline 2 & $\operatorname{IgG}$ & Serum & $(17.24 \pm 2.89) \mathrm{g} / \mathrm{l}$ & $\mathrm{C}$ & Kumar, S., et al. [78] \\
\hline 3 & IgM & Serum & $(1.38 \pm 0.31) \mathrm{g} / \mathrm{l}$ & $\mathrm{E}$ & Kumar, S., et al. [78] \\
\hline 4 & IgM & Serum & $(2.42 \pm 1.54) \mathrm{g} / \mathrm{l}$ & $\mathrm{C}$ & Kumar, S., et al. [78] \\
\hline 5 & IgA & Serum & $(2.05 \pm 1.13) \mathrm{g} / \mathrm{l}$ & $\mathrm{E}$ & Kumar, S., et al. [78] \\
\hline 6 & IgA & Serum & $(2.83 \pm 0.62) \mathrm{g} / \mathrm{l}$ & $\mathrm{C}$ & Kumar, S., et al. [78] \\
\hline 7 & $\mathrm{C}_{3}$ & Serum & $(1.53 \pm 0.25) \mathrm{g} / \mathrm{l}$ & $\mathrm{E}$ & Kumar, S., et al. [78] \\
\hline 8 & $\mathrm{C}_{3}$ & Serum & $(1.58 \pm 0.14) \mathrm{g} / \mathrm{l}$ & $\mathrm{C}$ & Kumar, S., et al. [78] \\
\hline 9 & $\mathrm{C}_{4}$ & Serum & $(0.26 \pm 0.13) \mathrm{g} / \mathrm{l}$ & $\mathrm{E}$ & Kumar, S., et al. [78] \\
\hline 10 & $\mathrm{C}_{4}$ & Serum & $(0.28 \pm 0.09) \mathrm{g} / \mathrm{l}$ & $\mathrm{C}$ & Kumar, S., et al. [78] \\
\hline 11 & $\operatorname{IgG}$ & Serum & $(17.2059 \pm 2.6317) \mathrm{g} / \mathrm{l}$ & $\mathrm{AD}$ & Present work \\
\hline 12 & IgG & Serum & $(17.6720 \pm 3.1457) \mathrm{g} / \mathrm{l}$ & Controls & Present work \\
\hline 13 & IgA & Serum & $(4.0288 \pm 1.4283) \mathrm{g} / \mathrm{l}$ & $\mathrm{AD}$ & Present work \\
\hline 14 & IgA & Serum & $(2.9110 \pm 0.6717) \mathrm{g} / \mathrm{l}$ & Controls & Present work \\
\hline 15 & IgM & Serum & $(1.5459 \pm 0.5568) \mathrm{g} / \mathrm{l}$ & $\mathrm{AD}$ & Present work \\
\hline 16 & IgM & Serum & $(2.4290 \pm 1.5455) \mathrm{g} / \mathrm{l}$ & Controls & Present work \\
\hline 17 & $\mathrm{C}_{3}$ & Serum & $(0.7952 \pm 0.1284) \mathrm{g} / \mathrm{l}$ & $\mathrm{AD}$ & Present work \\
\hline 18 & $\mathrm{C}_{3}$ & Serum & $(1.568 \pm 4.2571) \mathrm{g} / \mathrm{l}$ & Controls & Present work \\
\hline 19 & $\mathrm{C}_{4}$ & Serum & $(0.2682 \pm 0.2877) \mathrm{g} / \mathrm{l}$ & $\mathrm{AD}$ & Present work \\
\hline 20 & $\mathrm{C}_{4}$ & Serum & $(0.260 \pm 0.0968) \mathrm{g} / \mathrm{l}$ & Controls & Present work \\
\hline
\end{tabular}

Table 2. Regression and correlation coefficient of Alzheimer disease.

\begin{tabular}{|c|c|c|c|c|c|c|}
\hline S.No. & $\begin{array}{l}\text { Mode } \\
\text { of } \\
\text { Sample }\end{array}$ & Correlation Co. & $\begin{array}{c}\text { Partial Correlation } \\
\text { Coefficient }\end{array}$ & $\begin{array}{l}\text { Multiple Correlation } \\
\text { Coefficient }\end{array}$ & Regression Co. & Regression Equation \\
\hline \multirow{2}{*}{1} & A.D. & $\mathrm{r}_{\mathrm{GA}}=0.4006$ & $\mathrm{r}_{\mathrm{GA} . \mathrm{M}}=0.44815$ & $\mathrm{R}_{\mathrm{G} . \mathrm{AM}}=0.2186$ & $\begin{array}{l}\mathrm{b}_{\mathrm{GA}}=0.7381 \\
\mathrm{~b}_{\mathrm{AG}}=0.2174\end{array}$ & $\begin{aligned} \operatorname{IgG} & =0.7381 \operatorname{Ig} \mathrm{A}+14.2249 \\
\operatorname{Ig} A & =0.2174 \operatorname{IgG}+0.2983\end{aligned}$ \\
\hline & $\mathrm{C}$ & $=0.4442$ & $=0.45555$ & $=0.2105$ & $\begin{array}{l}\mathrm{b}_{\mathrm{GA}}=2.0789 \\
\mathrm{~b}_{\mathrm{AG}}=0.0949\end{array}$ & $\begin{array}{l}\operatorname{IgG}=2.0789 \operatorname{Ig} A+11.6204 \\
\operatorname{Ig} A=0.0949 \operatorname{IgG}+1.2340\end{array}$ \\
\hline \multirow[b]{2}{*}{2} & A.D. & $\mathrm{r}_{\mathrm{G} . \mathrm{M}}=0.1470$ & $\mathrm{r}_{\mathrm{AM} . \mathrm{G}}=0.3082$ & $\mathrm{R}_{\mathrm{A} . \mathrm{MG}}=0.2402$ & $\begin{aligned} \mathrm{b}_{\mathrm{GM}} & =0.6947 \\
\mathrm{~b}_{\mathrm{MG}} & =0.0311\end{aligned}$ & $\begin{array}{l}\operatorname{IgG}=0.6947 \operatorname{IgM}+16.132 \\
\operatorname{IgM}=0.0311 \operatorname{IgG}+1.0149\end{array}$ \\
\hline & $\mathrm{C}$ & $=0.0610$ & $=0.3912$ & $=0.3201$ & $\begin{array}{l}\mathrm{b}_{\mathrm{GM}}=0.1240 \\
\mathrm{~b}_{\mathrm{MG}}=0.0299\end{array}$ & $\begin{array}{c}\operatorname{IgG}=0.1240 \operatorname{IgM}+ \\
17.3709 \\
\operatorname{IgM}=0.0299 \operatorname{Ig} G+1.9007\end{array}$ \\
\hline \multirow{2}{*}{3} & A.D. & $\mathrm{r}_{\mathrm{MA}}=0.2205$ & $\mathrm{r}_{\mathrm{MG} . \mathrm{A}}=0.2633$ & $\mathrm{R}_{\mathrm{M} . \mathrm{AG}}=0.2478$ & $\begin{array}{l}\mathrm{b}_{\mathrm{MA}}=0.0859 \\
\mathrm{~b}_{\mathrm{AM}}=0.5656\end{array}$ & $\begin{array}{l}\operatorname{IgM}=0.0859 \operatorname{Ig} A+1.1990 \\
\operatorname{Ig} A=0.5656 \operatorname{IgM}+3.1645\end{array}$ \\
\hline & $\mathrm{C}$ & $=0.3770$ & $=0.1282$ & $=0.5162$ & $\begin{array}{l}\mathrm{b}_{\mathrm{MA}}=0.8674 \\
\mathrm{~b}_{\mathrm{AM}}=0.1638\end{array}$ & $\begin{array}{l}\operatorname{IgM}=0.8674 \operatorname{Ig} \mathrm{A}-0.096 \\
\operatorname{IgA}=0.1638 \operatorname{IgM}+2.5132\end{array}$ \\
\hline \multirow{2}{*}{4} & A.D. & $\mathrm{r}_{\mathrm{C}_{3} \mathrm{C}_{4}}=0.0669$ & - & - & $\begin{array}{l}\mathrm{b}_{\mathrm{C}_{3} \mathrm{C}_{4}}=0.0298 \\
b_{C_{4} C_{3}}=0.1498\end{array}$ & $\begin{array}{l}C_{3}=0.0298 C_{4}+0.7873 \\
C_{4}=0.1498 C_{3}+0.1491\end{array}$ \\
\hline & $\mathrm{C}$ & $\mathrm{r}_{\mathrm{C}_{3} \mathrm{C}_{4}}=0.0205$ & - & - & $\begin{array}{l}\mathrm{b}_{\mathrm{c}_{3} \mathrm{C}_{4}}=-0.9015 \\
\mathrm{~b}_{\mathrm{c}_{4} \mathrm{C}_{3}}=-0.0004\end{array}$ & $\begin{array}{l}C_{3}=-0.9015 C_{4}+1.8023 \\
C_{4}=-0.0004 C_{3}+0.2606\end{array}$ \\
\hline
\end{tabular}


Table 3. Student “t”-test-normal sample and Alzheimer disease.

\begin{tabular}{|c|c|c|c|c|c|c|}
\hline S.No. & Immunological Parameters & $t_{(\exp )}$ & $P$ value $\& d_{f}$ & $t_{\text {(theo) }}$ & Result & Null Hypothesis \\
\hline \multirow{2}{*}{1} & \multirow{2}{*}{ IgG } & 0.592 & 0.9541 (Paired) $d_{f}=9$ & 0.70 & $t_{\text {theo }}>t_{\exp }$ & Rejected \\
\hline & & 0.4318 & $0.6826\left(\right.$ Unpaired) $d_{f}=25$ & 0.68 & $t_{\text {theo }}>t_{\text {exp }}$ & Rejected \\
\hline \multirow{2}{*}{2} & \multirow{2}{*}{ IgM } & 2.1254 & 0.0625 (Paired) $d_{f}=9$ & 1.83 & $t_{\exp }>t_{\text {theo }}$ & Accepted \\
\hline & & 2.1540 & 0.0411 (Unpaired) $\mathrm{d}_{\mathrm{f}}=25$ & 2.06 & $t_{\exp }>t_{\text {theo }}$ & Accepted \\
\hline \multirow{2}{*}{3} & \multirow{2}{*}{ IgA } & 2.2982 & 0.0471 (Paired) $d_{f}=9$ & 2.26 & & \\
\hline & & 2.3357 & 0.0278 (Unpaired) $\mathrm{d}_{\mathrm{f}}=25$ & 2.06 & $t_{\exp }>t_{\text {theo }}$ & Accepted \\
\hline \multirow{2}{*}{4} & \multirow{2}{*}{$\mathrm{C}_{3}$} & 9.4865 & 0.001 (Paired) $\mathrm{d}_{\mathrm{f}}=8$ & & & \\
\hline & & 13.6028 & 0.0001 (Unpaired) $\mathrm{d}_{\mathrm{f}}=24$ & & & \\
\hline \multirow{2}{*}{5} & \multirow{2}{*}{$\mathrm{C}_{4}$} & 0.0549 & $0.9575\left(\right.$ Paired) $d_{f}=8$ & & & \\
\hline & & 0.1633 & 0.8717 (Unpaired) $\mathrm{d}_{\mathrm{f}}=24$ & & & \\
\hline
\end{tabular}

Our findings on immunoglobulins and complements show that the levels of IgG in Alzheimer's disease do not change and completely resemble with controls. Levels of IgM go down up to 62.5\% in Alzheimer's disease in comparison to controls. A drastic change in the levels of IgA has been seen and found that these levels go up to $137.9 \%$ in comparison to healthy controls.

The levels of $\mathrm{C}_{3}$ go down up to $52.66 \%$ in comparison to normals. The levels of $\mathrm{C}_{4}$ do not show any change in the present study.

\section{Discussion}

Central nervous system (CNS) is relatively isolated from systemic immune response in the absence of disease. There is no mechanism found for antibody production within the normal condition of CNS. This system has been described as an immunologically privileged site due to paucity of normal immune surveillance. If a virus penetrates the blood brain barrier (BBB) that excludes most infectious agents, the same barrier may stop viral clearance. Immune responses in the CNS during infection are recruited from the systemic circulation in a relatively selective and specific fashion. Cells and antibodies found in the CNS during infections differ from these that follow non specific rupture in the BBB. During the stage of viral infection, we have an early increase in permeability of vessels, which allow transudation of serum proteins, cell entry is immunologically specific. The cells, which are entering have a specific kinetics and do not simply mirror the proportions of cell phenotypes in the blood. These cells in turn are caused to replicate cells, which may persist for long periods of time within CNS. On the basis of the above mentioned facts a review immune response in the CNS is quit necessary and required. Some of the researchers have proposed the hypothesis of immunological mechanism for the involvement of pathogenesis in Alzheimer's disease. Many of the patients of AD have immune deficient state.

It is believed that the changes in the levels of immunological parameters in the present study and after the review of the literature are due to manifestation of the factors, which are responsible for this disease. Immunity is related with the food, which we eat. It has already been established that content of the food have some trace elements. The trace elements play a role in human immunity. If the level of these elements goes beyond the limit of normalcy even death may occur. On the other hand, if the levels are lower side of the normal range something unnatural can happen. A relation between immunoglobulin complement and trace element is considered in the future preview of the study.

Our findings show that the value of IgG in serum of Alzheimer's Disease patients is (17.2059 \pm 2.6317$) \mathrm{g} / \mathrm{l}$ and in controls, i.e. $(17.6720 \pm 3.1457) \mathrm{g} / \mathrm{l}$. Values of IgM in AD patients go down up to $62.5 \%$ in comparison to healthy subjects. A sudden change was observed in the levels of IgA of AD patients. It has been put on the value $137.9 \%$ high in comparison to healthy subjects. The levels of complement $C_{3}$ has also value of lower side and go down up to $52.66 \%$ in $\mathrm{AD}$ patients. The value of levels of complement $\mathrm{C}_{4}$ shows no deflection from the control 
values.

Regression and multiple correlation analysis give a good presentation of our work. It has been found that the partial correlation coefficients $\mathrm{r}_{\mathrm{GA} . \mathrm{M}}$, which has value 0.44815 in $\mathrm{AD}$ patients and 0.45555 in controls. We have found that these correlations do not show any resemblance and do not show any deflection, while $\mathrm{r}_{\mathrm{Am} . \mathrm{G}}$ has value 0.3082 in AD patients and 0.3912 in controls slightly better correlated in comparison to healthy controls. There is a correlation such as $r_{M G . A}$ has a variation more than fifty percent for control values. Multiple correlation $\mathrm{R}_{\mathrm{G} . \mathrm{AM}}$ has a trend and does not show any change in comparison to healthy controls, while $\mathrm{R}_{\mathrm{A} . \mathrm{MG}}$ has strongly correlation in comparison to controls. $\mathrm{R}_{\mathrm{M} . \mathrm{AG}}$ is also strongly correlated. Regression coefficients and regression equations are basic foundations of correlations measurements and show a specific character of variation.

\section{Conclusion}

On the basis of analysis of immunoglobulins and complements, we have reached at a point where we can give some ideas related to study of Alzheimer's disease. The measured values of levels of immunoglobulins and complements have a variation. Statistical variations such as regression and correlation analysis with a test called Student " $t$ "-test were employed to the present work. The variations are in the present work. The measured levels of IgA have gone up to $137.9 \%$ on the higher side in comparison to healthy subjects. The levels of IgM were lower up to $62.5 \%$ in comparison to normals. The levels of complements $\mathrm{C}_{3}$ were also found on the lower side up to $52.66 \%$ in comparison to healthy subjects. The alterations in the immunoglobulogical parameters are a subject of study, which can give more information related to Alzheimer's disease. We can say that the present study is a step in understanding the mechanism of the immunological changes in the brain of Alzheimer's disease patients. On the basis of partial and multiple correlation analysis, a trend has been found between all the immunoglobulins, which is given here as
1) $r_{G A}>r_{M A}>r_{G . M}$
2) $r_{\text {GA.M }}>r_{\text {AM.G }}>r_{M G . A}$
3) $R_{\text {A.MG }}>R_{M . A G}>R_{G . A M}$.

\section{Acknowledgements}

The authors are thankful to Dr. P.K. Saxena, Principal, D.A.V. College, Muzaffarnagar for providing the facility of doing work. We are also thankful to Medical Superintendent, Safdarjang Hospital, New Delhi, for arranging the blood samples of the diseased and healthy controls. Our thanks go to Dr. Manju Chauhan, Head, Department of Biosciences, D.A.V. College, Muzaffarnagar for providing the facilities of estimation of the immunological parameters from sera of different blood samples of the human disorders and controls.

\section{References}

[1] Sambat, L. (1994) Historical Perspectives. In: Handy, R.C., Turnbull, J.M., Clark, W. and Lan Caster, M.N., Eds., Alzheimer's Disease. A Hand Book for Care Givers, 2nd Edition, Mosby-Year Book Inc., St. Louis, 51-59.

[2] Reger, B. (2002) Alzheimer's Disease: A Brief History and Avenues for Current Research. Journal of Young Investigatros, 6, 1-5.

[3] Whaley, N.S. (2002) Senility, Confusion, Debate Fear: Conceptualizing Alzheimer's Disease and the History of Senile Dementia. Thesis, Drew University, Madism.

[4] Ronald, C.H. and Turnbull, J.M. (1994) Alzheimer's Disease: An Overview. In: Handy, R.C., Turnbull, J.M., Clark, W. and Lancaster, M.N., Eds., Alzheimer's Disease. A Hand Book for Care Givers, 2nd Edition, Mosby-Year Book Inc., St. Louis, 1-7.

[5] Cohen, G.D. (2002) Historical Views and Evolution of Concepts. In: Reisberg, B., Ed., Alzheimer's, Disease, The Free press Macmillan Inc., New York, 29-33.

[6] Rebeca, C.B., Alan, H.L. and Baba Saheb, R.S. (2005) Neuro Degenerative Disease: An Overview of Environmental Risk Factors. Environmental Health Perspectives, 113, 1250-1256. http://dx.doi.org/10.1289/ehp.7567

[7] Ronald, C.H. and Lorry, B.H. (1994) Factors That Aggravate the Symptoms. In: Handy, R.C., Turnbull, J.M., Clark, W. and Lancaster, M.N., Eds., Alzheimer's Disease. A Hand Book for Care Givers, 2nd Edition, Mosby—Year Book Inc., St. Louis, 104-116.

[8] Greig, N.H. (2004) New Therapeutic Strategies and Drug Candidates for Neurodegenrative Disease: P53 and TNF- 
Alpha Inhibitors, and GLP-1 Recepter Agonists. Annals of the New York Academy of Sciences, 1035, 290-315. http://dx.doi.org/10.1196/annals.1332.018

[9] Patterson, C., Feightner, J.W., Garcia, A.H., Sing, G.Y., Macknight, C. and Sadovnivk, A.D. (2008) Diagnosis and Treatment of Dementia: 1. Risk Assessment and Primary Prevention of Alzheimer's Disease. Canadian Medical Association Journal, 178, 548-556. http://dx.doi.org/10.1503/cmaj.070796

[10] Rosendorff, C., Beeri, M.S. and Silverman, J.M. (2007) Cordiovascular Risk Factors for Alzheimer's Disease. The American Journal of Geriatric Cardiology, 16, 143-149. http://dx.doi.org/10.1111/j.1076-7460.2007.06696.x

[11] Solfrizzi, V. (2008) Life Style Related Factors in Predementia and Dementia Syndromes. Expert Review of Neurotherapeutics, 8, 133-158. http://dx.doi.org/10.1586/14737175.8.1.133

[12] Masters, C.L., Simmus, G., Weinwan, N.A., Multhaup, G., Mc Donald, B.L. and Beyreuther, K. (1985) Amyloid Plaque Core Protein in Alzheimer's Disease and Down Syndrome. Proceedings of the National Academy of Sciences of the United States of America, 82, 4245-4249. http://dx.doi.org/10.1073/pnas.82.12.4245

[13] Glenner, G.G. and Wong, C.W. (1984) Alzheimer's Disease, Initial Report of the Purification and Characterization of a Novel Corebrovascular Amyloid Protein. Biochemical and Biophysical Research Communications, 120, 885-890. http://dx.doi.org/10.1016/S0006-291X(84)80190-4

[14] Panza, F., Capurso, C., D’Introno, A., Colacicco, A.M., Frisardi, V., Lorusso, M., Santamato, A., Seripa, D., Pilotto, A., Scafato, E., Vendemiate, G., Capurse, A. and Solfrizzi, V. (2009) Alcohol Drinking, Cognitive Functions in Older Age, Predementia and Dementia Syndromes. Journal of Alzheimer's Disease, 17, 7-31.

[15] Stern, Y.C. (2006) Cognitive Reserve and Alzheimer's Disease. Alzheimer's Disease and Associated Disorders, 20, 112-117.

[16] Makinodan, T.C. (1976) Immunobiology of Aging. Journal of the American Geriatrics Society, 24, $249-252$.

[17] Burch, P.R.J. (1968) An Inquiry Concerning Growth, Disease and Aging. In: Edinburge, Oliver. http://dx.doi.org/10.1093/aje/152.1.59

[18] Burnet, F.M. (1970) An Immunological Approach of Aging. The Lancet, 296, 358-360. http://dx.doi.org/10.1016/S0140-6736(70)92886-2

[19] Kay, M.M.B. and Makinodan, T. (1976) Immunobiology of Aging: Evaluation of Current Status. Clinical Immunology and Immunopathology, 6, 394-413.

[20] Weksler, M.C., Inners, J.D. and Goldstein, G. (1978) Immunological Studies of Aging IV. The Contribution of Thymic Involution to the Immune Deficiencies of Aging Mice and Reversal with Thymopoietin 32-36. Journal of Experimental Medicine, 148, 996-1006. http://dx.doi.org/10.1084/jem.148.4.996

[21] Weksler, M.E. (1981) The Senescence of the Immune System. Hospital Practice, 16, 53-64.

[22] Wisniewski, H.M. and Terry, R.D. (1973) Morphology of Aging Brain, Human and Animal. Progress in Brain Research, 40, 167-186. http://dx.doi.org/10.1016/S0079-6123(08)60686-X

[23] Bluestein, H.G. (1978) Neurocytotoxic Antibodies in Serum of Patients with Systemtic Lupus Erythematosus. Proceedings of the National Academy of Sciences of the United States of America, 75, 3965-3969. http://dx.doi.org/10.1073/pnas.75.8.3965

[24] Heath, R.G. and Krupp, I.M. (1967) Schizophrenia as an Immunologic Disorder. JAMA Psychiatry, 16, 1-9. http://dx.doi.org/10.1001/archpsyc.1967.01730190003001

[25] Motycka, A. and JezKova, Z. (1975) Auto Antibodies and Brain Ischemia Topography. Casopís Lékar̆ů Ceských, 114, 1455-1457.

[26] Sakalickova, O., Jezkova, Z. and Jezkova, V. (1962) Immunological Aspects of Psychiatric Gerontology. Review of Czechoslovak Medicine, 8, 264-275.

[27] Pandey, R.S., Gupta, A.K. and Chaturvedi, U.C. (1981) Autoimmune Model of Schizophrenia with Special Reference to Antibrain Antibodies. Biological Psychiatry, 16, 1123-1135.

[28] Husby, G., van de Rijn, I., Zabriska, J.B., Abdin, Z.H. and Williams Jr., R.C. (1976) Antibodies Reacting with Cytoplasm of Subthalamic and Caudate Nuclei Neurons in Chorea and Acute Rheumatic Fever. Journal of Experimental Medicine, 144, 1094-1110. http://dx.doi.org/10.1084/jem.144.4.1094

[29] Diederrichsen, H. and Pyndt, I.C. (1968) Antibodies against Neurons in a Patient with Systemtic Lupus Erythematosus, Cerebral Palsy and Epilepsy. Brain, 93, 407-412. http://dx.doi.org/10.1093/brain/93.2.407

[30] Ingram, C.R., Phegan, K.J. and Blumenthal, H.T. (1974) Significance of an Aging-Linked Neuron Binding Gamma Globulin Fraction of Human Sera. Journal of Gerontology, 29, 20-27. http://dx.doi.org/10.1093/geronj/29.1.20

[31] Lal, H. and Forster, M.J. (1988) Autoimmunity and Age-Associated Cognitive Decline. Neurobiology of Aging, 9, 733743. http://dx.doi.org/10.1016/S0197-4580(88)80141-6 
[32] Luber-Narod, J. and Rogers, J. (1988) Immune System Associated Antigens Expressed by Cells of the Human Central Nervous System. Neuroscience Letters, 94, 17-22. http://dx.doi.org/10.1016/0304-3940(88)90263-7

[33] Rogers, J., Luber-Narod, J., Styren, S.D. and Civin, W.H. (1988) Expression of Immune System-Associated Antigens by Cells of the Human Central Nervous System: Relationship to the Pathology of Alzheimer's Disease. Neurobiology of Aging, 9, 339-349. http://dx.doi.org/10.1016/S0197-4580(88)80079-4

[34] Styren, S.D., Civin, W.H. and Rogers, J. (1990) Molecular, Cellular and Pathologic Characterization of HLA-DR Immunoreactivity in Normal Elderly and Alzheimer's Disease Brain. Experimental Neurology, 110, 93-104. http://dx.doi.org/10.1016/0014-4886(90)90054-V

[35] McGeer, P.L., Akiyama, H., Itagaki, S. and McGeer, E.G. (1990) Immune System Response in Alzheimer’s Disease. Canadian Journal of Neurological Sciences, 16, 516-527.

[36] McGeer, P.L., Itagaki, S., Tago, H. and McGeer, E.G. (1987) Reactive Microglia in Patients with Senile Dementia of the Alzheimer's Type Are Positive for the Histocompatibility Glycoprotein HLA-DR. Neuroscience Letters, 79, 195200. http://dx.doi.org/10.1016/0304-3940(87)90696-3

[37] McGeer, P.L., Itagaki, S., Boyer, B.E. and McGeer, E.G. (1988) Reactive Microglia Are Positive for HLA-DR in the Substantia Nigra of Parkinson's and Alzheimer's Disease Brains. Neurology, 20, 1285-1291. http://dx.doi.org/10.1212/WNL.38.8.1285

[38] McGeer, P.L., Itagaki, S. and McGeer, E.G. (1988) Expression of the Histocompatibility Glycoprotein HLA-DR in Neurological Disease. Acta Neuropathologica, 76, 550-557. http://dx.doi.org/10.1007/BF00689592

[39] Itagaki, S., McGeer, P.L., Akiyama, H., Zhu, S. and Selkoe, D. (1989) Relationship of Microglia and Astrocytes to Amyloid Deposits of Alzheimer Disease. Journal of Neuroimmunology, 24, 173-182. http://dx.doi.org/10.1016/0165-5728(89)90115-X

[40] Yamada, T., Akiyama, H. and McGeer, P.L. (1990) Complement-Activated Oligodendroglia: A New Pathologenic Entity Identified by Immunostaining with Antibodies to Human Complement Proteins $\mathrm{C}_{3} \mathrm{~d}$ and $\mathrm{C}_{4} \mathrm{~d}$. Neuroscience Letters, 112, 161-166. http://dx.doi.org/10.1016/0304-3940(90)90196-G

[41] Bouras, C., Riederer, B.M., Kovari, E., Hof, P.R. and Giannakopoulos, P. (2005) Humoral Immunity in Brain Aging and Alzheimer's Disease. Brain Research Reviews, 48, 477-487. http://dx.doi.org/10.1016/j.brainresrev.2004.09.009

[42] Roitt, I., Brostoff, J. and Male, D. (1985) Immunology. 2nd Edition, C.V. Mosby, St Louis, 459.

[43] Coleman, R.M., Lombard, M.F. and Sicard, R.E. (1992) Fundamental Immunology. Wm. C. Brown Publishers, Dubugue, 459.

[44] Bahananyer, S., Moreau-Dubois, M., Brown, P., Cathala, F. and Gajdvsek, D.C. (1983) Serum Antibodies to Neurofilament Antigens in Patients with Neurological and Other Disease and in Health Controls. Journal of Neuroimmunology, 5, 191-196.

[45] Gaskin, F., Kingsley, B.S. and Fu, S.M. (1987) Autoantibodies to Neurofibrillary Tangles and Brain Tissue in Alzheimer's Disease. Establishment of Epstein-Barr Virus-Transformed Antibody-Producing Cell Lines. Journal of Experimental Medicine, 165, 245-250. http://dx.doi.org/10.1084/jem.165.1.245

[46] Terry, R.D., Peck, A., DeTeresa, R., Schechter, R. and Horoupian, D.S. (1981) Some Morphometric Aspects of the Brain in Senile Dementia of the Alzheimer Type. Annals of Neurology, 10, 184-192. http://dx.doi.org/10.1002/ana.410100209

[47] Rogers, J. and Morrison, J. (1985) Quantitative Morphology and Regional and Laminar Distributions of Senile Plaques in Alzheimer's Disease. Journal of Neuroscience, 5, 2801-2808.

[48] Rogers, J., Harold, C.W., Styren, S.D. and McGeer, P.L. (1992) Immune-Related Mechanisms of Alzheimer’s Disease Pathogenesis. In: Khachaturian, Z.S. and Blass, J.P., Eds., Alzheimer's Disease: New Treatment Strategies, Marcel Dekkar, Inc, New York, 147-163.

[49] Gottfries, C.G. (1983) Biochemical Changes in Blood and Cerebrospinal Fluid. In: Reisberg, B., Gottfries, C.G., Blennow, K., Karlsson, I. and Wallin, A., Eds., The Neurochemistry of Alzheimer's Disease, Free Press, Collier MacMillan, London, 122-130.

[50] Cohen, D., Matsuyama, S.S. and Jarvik, L.F. (1976) Immunoglobulin Levels and Intellectual Functioning in the Aged: Short Commun. Journal of the Neurological Sciences, 49, 293-303.

[51] Williams, A., Papadopoulos, N. and Chase, T.N. (1980) Demonstration of CSF Gamma-Globulin Banding Presenile Dementia. Neurology, 30, 882-884. http://dx.doi.org/10.1212/WNL.30.8.882

[52] Rozemuller, J.M., Eikelenboom, P., Stam, F.C., Befreuther, K. and Masters, C.L. (1989) A4 Protein in Alzheimer's Disease: Primary and Secondary Cellular Events Extracellular Amyloid Deposition. Journal of Neuropathology \& Experimental Neurology, 48, 674-691. http://dx.doi.org/10.1097/00005072-198911000-00009

[53] Eikelenboom, P. and Stam, F.C. (1982) Immunoglobulins and Complement Factors in Senile Plaques. Acta Neuropa- 
thologica, 57, 239-242. http://dx.doi.org/10.1007/BF00685397

[54] McGeer, P.L., Akiyama, H., Itagaki, S. and McGeer, E.G. (1989) Immune System Response in Alzheimer’s Disease. Canadian Journal of Neurological Sciences, 16, 516-527.

[55] Rogers, J., Schultz, J., Brachova, L., Lue, L.F., Webster, S., Bradt, B., Cooper, N.R. and Moose, D.E. (1992) Complement Activation and $\beta$-Amyloid-Mediated Neurotoxicity in Alzheimer's Disease. Research in Immunology, 143, 624630. http://dx.doi.org/10.1016/0923-2494(92)80046-N

[56] McGeer, P.L. and McGeer, E.G. (1992) Complement Proteins and Complement Inhibitors in Alzheimer's Disease. Research in Immunology, 143, 621-624. http://dx.doi.org/10.1016/0923-2494(92)80045-M

[57] Eikelenboom, P., Hack, C.E., Kamphorst, W., Vander Walk, P., Vannostrand, W.E. and Rozemuller, J.M. (1993) The Sequence of Neuroimmunological Events in Cerebral Amyloid Plaque Formation in Alzheimer's Disease. In: Corain, B., Iqbal, K., Nicolini, B.M., Winblad, B., Wisniewski, H. and Zatta, P., Eds., Alzheimer's Disease: Advances in Clinical and Basic Research, John Wiley \& Sons Ltd., Hoboken, 165-170.

[58] Fillits, H., Luine, V.N., Reisberg, B., Amador, R., Mcewen, B. and Zabriskie, J.B. (1985) Studies of the Specificity of Antibrain Antibodies in Alzheimer's Disease. Neurol.Neurobiol., 18, 307-318.

[59] Fillits, H.M., Kemeny, E., Luine, V., Weksler, M.E. and Zabriskie, J.B. (1987) Antivascular Antibodies in the Sera of Patients with Senile Dementia of the Alzheimer's Type. Journal of Gerontology, 42, 180-184. http://dx.doi.org/10.1093/geronj/42.2.180

[60] Singh, V.K. and Fudenberg, H.H. (1986) Detection of Brain Autoantibodies in the Serum of Patients with Alzheimer's Disease but Not in Down's Syndrome. Immunology Letters, 12, 277-280. http://dx.doi.org/10.1016/0165-2478(86)90030-1

[61] Sugiura, M., Yokoi, Y., Maruyama, S., Ishido, T., Tokunaga, Y. and Sasaki, K. (1989) Detection of Anti-Cerebral Autoantibodies in Schizophrenia and Alzheimer's Disease. Journal of Clinical \& Laboratory Immunology, 28, 1-3.

[62] Cohen, D. and Eisdorfer, C. (1980) Serum Immunoglobulins and Cognitive Status in the Elderly: 1. A Population Study. British Journal of Psychiatry, 136, 33-39. http://dx.doi.org/10.1192/bjp.136.1.33

[63] Eisdorfer, C. and Cohen, D. (1980) Serum Immunoglobulins and Cognitive Status in the Elderly: 2. An Immunological Behavioral Relationship? British Journal of Psychiatry, 136, 40-45. http://dx.doi.org/10.1192/bjp.136.1.40

[64] Koustsocraki, E. (2008) Immunotherapy in Alzheimer’s Disease. Encephalos, 45, 237-240.

[65] Morgan, B.P., Gasque, P., Singhrao, S. and Piddleshden, S.J. (1997) The Role of Complement in Disorders of the Nervous System. Immunopharmacology, 38, 43-50. http://dx.doi.org/10.1016/S0162-3109(97)00059-3

[66] Bonifati, D.M. and Kishore, U. (2007) Role of Complement in Neurodegeneration and Neuroinflammation. Molecular Immunology, 44, 999-1010. http://dx.doi.org/10.1016/j.molimm.2006.03.007

[67] Eikelenboom, P. and Veerhvis, R. (1995) The Role of Complement and Activated Microglia in the Pathogenesis of Alzheimer's Disease. Neurobiology of Aging, 17, 673-680. http://dx.doi.org/10.1016/0197-4580(96)00108-X

[68] Watts, H., Kennedy, P.G.E. and Thomas, M. (1981) The Significance of Anti-Neuronal Antibodies in Alzheimer's Disease. Journal of Neuroimmunology, 1, 107-116. http://dx.doi.org/10.1016/0165-5728(81)90013-8

[69] Jean, M.S., Marie, C.B. and Gilbert, C. (1994) Comparative Immunohistochemical Characteristics of Human Choroid Plexus in Vascular and Alzheimer's Dementia. Human Pathology, 125, 1185-1190.

[70] Elovaara, I., Lean, A., Palo, J. and Erkinjuntti, T. (1985) CSF in Alzheimer’s Disease: Studies on Blood Brain Barrier Function and Intrathecal Protein Synthesis. Journal of the Neurological Sciences, 70, 73-80. http://dx.doi.org/10.1016/0022-510X(85)90189-3

[71] Nerenberg, S.T., Prasad, R. and Rothman, M.E. (1978) Cerebrospinal Fluid IgG, IgA, IgM, IgD and IgE Levels in Central Nervous System Disorders. American Academy of Neurology, 28, 988-990. http://dx.doi.org/10.1212/WNL.28.10.988

[72] Selkoe, D.J. (1989) Biochemistry of Altered Brain Proteins in Alzheimer's Disease. Annual Review of Neuroscience, 12, 463-490. http://dx.doi.org/10.1146/annurev.ne.12.030189.002335

[73] Hampel, H., Müller-Spahn, F., Berger, C., Habert, A., Ackenheil, M. and Hook, C. (1995) Evidence of Blood-Cerebrospinal Fluid-Barrier Impairment in a Subgroup of Patients with Dementia of the Alzheimer Type and Major Depression: A Possible Indicator for Immuno Activation. Dementia and Geriatric Cognitive Disorders, 6, 348-354. http://dx.doi.org/10.1159/000106969

[74] Bouras, C., Riederer, B.M., Kövari, E., Hof, P.R. and Giannakopoulos, P. (2005) Humoral Immunity in Brain Aging and Alzheimer's Disease. Brain Research Reviews, 48, 477-487. http://dx.doi.org/10.1016/j.brainresrev.2004.09.009

[75] Veerhuis, R., Van der Valk, P., Janssen, I.J., Zhan, S.S., Van Nostrand, W.E. and Eikelenboom, P. (1995) Complement Activation in Amyloid Plaques in Alzheimer's Disease Brains Does not Proceed Further than $\mathrm{C}_{3}$. Virchows Archiv, 426, 
603-610.

[76] Kalaria, R.N., Kroon, S.N. and Perry, G. (1993) Serum Proteins and the Blood-Brain Barrier in the Pathogenesis of Alzheimer's Disease. In: Nicolini, M., Zatta, P.F. and Corain, B., Eds., Alzheimer's Disease and Altered Disorders, Pergamum Press, Oxford, 281-282.

[77] Kayed, R., Jacksen, G.R., Ester, D.M. and Barrett, A.D. (2011) Alzheimers Disease: Review of Emerging Treatment Role for Intravenous Immunoglobulins. Journal of Central Nervous System Disease, 3, 67-73.

[78] Kumar, S., Kumar, V., Jain, D.C. and Mittal, R. (2013) Immunological Variations in Epileptic Children. Open Journal of Applied Sciences, 3, 71-91. http://dx.doi.org/10.4236/ojapps.2013.31012

[79] Mancini, G., Carbonara, A.O. and Heremans, J.F. (1965) Immunochemical Quantitation of Antigens by Single Radical Immunodiffusion. Immunochemistry, 2, 235-254. http://dx.doi.org/10.1016/0019-2791(65)90004-2 